\section{Kentucky-Southern Indiana}

An organizational meeting was held on 16 June 1995. Eight AMS members, representing the United Parcel Service, the Kentucky Transportation Cabinet, NWS, and WDRB-TV, and one non-AMS member attended the meeting. Attendees voted on chapter dues, meeting schedules, and officers. The first slate of officers are Bill Wilson of the NWS, president; Tammy Garrison of WDRB-TV, vice president; and Marvin Maddox of the NWS, secretary/treasurer. The new Kentucky-Southern Indiana chapter member Marilyn Scholz, a member of the former Derby City chapter, which became inactive approximately 15 years ago, announced that she had retained the records and funds of the inactive chapter and then transferred them to the Kentucky-Southern Indiana chapter. -Marvin Maddox.

\section{High Plains}

The AMS Executive Committee approved the organization of a new chapter at its meeting on 28 and 29 July. The new chapter, representing the western por- tion of the state of Kansas, is aptly named the High Plains chapter. Anyone in the Goodland, Kansas, area who is interested in attending meetings should contact Scott A. Mentzer, 920 Armory Rd., Goodland, KS 67735-9273; telephone: $913-899-2360$ or 7119.

\section{Northeast Ohio}

The chapter's annual picnic was held on 22 July 1995 at the MetroParks Brecksville Reservation. The feature of the picnic was a weather observing and forecasting session. Members and guests provided their own portable weather equipment, such as handheld anemometers and sling psychrometers, to observe and forecast. The appropriate numerical modeling was obtained from the National Weather Service (NWS) the previous day.-Matt Higgins.

\section{Headquarters}

The December Bulletin will report the outcome of this year's science fairs. Please submit resultsnamely, winners, projects, and schools-to Bulletin News Editor; e-mail: jburba@ametsoc.org •

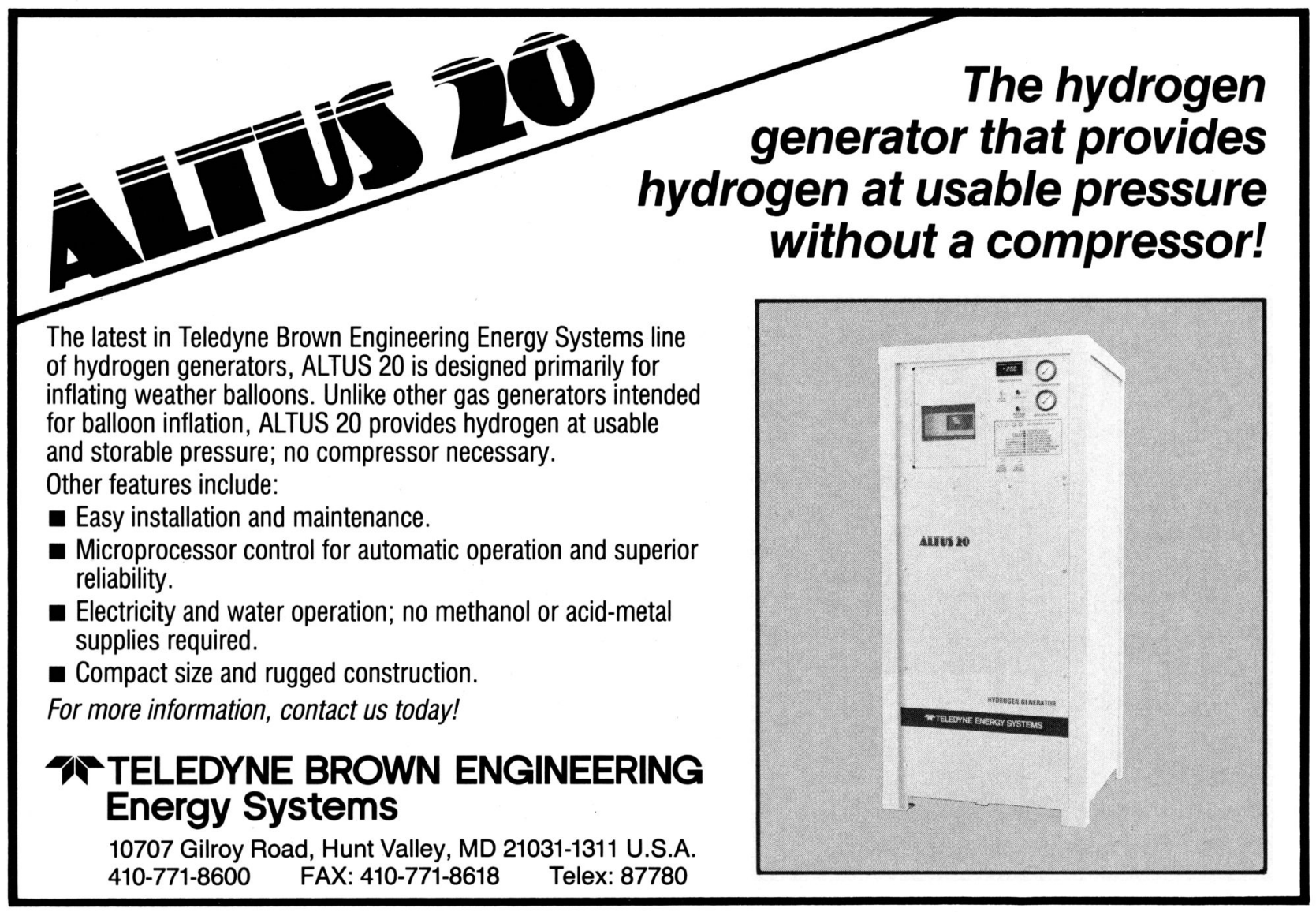

